\title{
Value (co-)creation in B2B sales ecosystems
}

\author{
Sami Rusthollkarhu \\ Unit of Industrial Engineering and Management, Tampere University, Tampere, Finland \\ Pia Hautamaki \\ Unit of Business, Tampere University of Applied Sciences, Tampere, Finland, and \\ Leena Aarikka-Stenroos \\ Unit of Industrial Engineering and Management, Tampere University, Tampere, Finland
}

\begin{abstract}
Purpose - Digital ecosystemic business environments challenge dyadic approaches to value creation and particularly to business-to-business (B2B) sales. This paper aims to offer a novel conceptualization of the connection between value creation and B2B sales, which indicates practical implications and builds an agenda for future research.

Design/methodology/approach - This conceptual paper integrates theoretical insights on service-dominant logic, service ecosystems, interactional value c0-creation and B2B sales. This paper uses anecdotal evidence from the field of B2B sales to illustrate theoretical concepts developed in the paper.

Findings - The paper develops the concept of value idea emergence (VIE), the process through which B2B entities become aware of a pursuable benefit. The paper further proposes that value (co-)creation in ecosystems happens through VIE's intertwinement with the process of value proposition creation, a process, which includes all activities needed to bring a value proposition to a customer. The paper then discusses the role of B2B in these processes and proposes an agenda for future research.

Practical implications - The novel conceptualizations of value (co-)creation can help B2B sales managers to understand the ecosystemic nature of the interactions that affect sales and value creation in the current business environment.

Originality/value - The paper contributes to the literature on B2B sales and value creation by proposing a novel concept of VIE, introducing a conceptual model of interactive value (co-)creation in ecosystems and reformulating the role of B2B sales in value creation. These theory-developing insights can be used to guide both academic and managerial attention to interactions happening in the ecosystem outside of the buyer-seller dyad.
\end{abstract}

Keywords Interaction, Co-creation, Value creation, Digitalization, Ecosystem, B2B sales

Paper type Conceptual paper

\section{Introduction}

Value creation in business-to-business (B2B) situations and particularly in B2B sales, has recently undergone rapid changes, becoming more complex, digital and systemic (Akaka and Vargo, 2014; Hartmann et al., 2018; Moncrief, 2017). This has challenged the conventional perception that value is created through dyadic interactions between B2B buyers and sellers (Grönroos and Voima, 2013; Haas et al., 2012; Hohenschwert and Geiger, 2015). The scope of value-creating interactions has widened as digitalization has enabled global competition (Marcos Cuevas, 2018) and helped to introduce non-traditional actors (e.g. outside consultants and industry experts) to both $\mathrm{B} 2 \mathrm{~B}$ value creation and sales processes (Hartmann et al., 2018). This shift towards the partly digital and ecosystemic environment of B2B sales has been acknowledged, but not yet fully explored. Hence, this paper aims to build a novel conceptual understanding of the connection between $\mathrm{B} 2 \mathrm{~B}$ sales and value creation in

The current issue and full text archive of this journal is available on Emerald Insight at: https://www.emerald.com/insight/0885-8624.htm

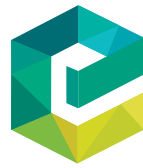

Journal of Business \& Industrial Marketing 36/4 (2021) 590-598

Emerald Publishing Limited [ISSN 0885-8624]

[DOI 10.1108/JBIM-03-2020-0130] ecosystemic settings, to provide practical implications and to propose an agenda for future research.

Due to changes in the business environment introduced by digitalization, value-creating interactions do not only occur in sales processes shared by the customer and the provider. In fact, most of the interactions within B2B customers' buying process take place through digital means outside of the buyerseller dyad (Steward et al., 2019; Lemon and Verhoef, 2016). This paper proposes a conceptualization of value creation in an ecosystemic setting and how this is reflected in B2B sales. It builds on a recent ecosystemic conceptualization, which defines sales as:

The interaction between actors aimed at creating and maintaining thin crossing points - the locations at which service can be efficiently exchanged

(C) Sami Rusthollkarhu, Pia Hautamaki and Leena Aarikka-Stenroos. Published by Emerald Publishing Limited. This article is published under the Creative Commons Attribution (CC BY 4.0) licence. Anyone may reproduce, distribute, translate and create derivative works of this article (for both commercial and non-commercial purposes), subject to full attribution to the original publication and authors. The full terms of this licence may be seen at http://creativecommons.org/licences/by/4.0/legalcode

This study is part of the ROBINS research project funded by Business Finland 2019-2022 (document numbers 7885/31/2018 and 7802/31/2018).

Received 2 March 2020

Revised 9 July 2020

Accepted 20 August 2020 
for service - through the ongoing alignment of institutional arrangements and the optimization of relationships (Hartmann et al., 2018, p. 9).

This definition sees value as being created in thin crossing points, where service exchange between customer and provider is possible. The thinness or thickness of crossing points refers to the simplicity of the interaction required for the exchange (Hartmann et al., 2018). Thin crossing points permit an exchange through shallow and simple interactions, whereas thick crossing points require the development of complex interactions for the exchange to occur (Baldwin, 2008). It is also worth highlighting that, in addition to the sales personnel of the provider, actors from multiple organizations can participate in selling activities, including actors working for the buying organization (Hartmann et al., 2018; Paesbrugghe et al., 2018).

Hartmann et al. (2018) emphasize sales that happen through dialogic interactions. However, from the perspective of value creation, focussing purely on dialogical interactions only partially captures the complexity within ecosystemic environments. Buyers' expectations and actions are greatly affected by unidirectional interactions, where the level of trust between actors is not sufficient to engage in dialogue (Ballantyne and Varey, 2006) or engagement does not happen for other reasons. For example, web pages (D'Haen et al., 2016) or blog posts by industry experts (Zanette et al., 2013) are not always dialogical by nature but might include information or other stimuli that affect buyers' expectations. The expectations formed by previous dialogical and unidirectional interactions greatly affect consecutive dialogical interactions, as well as the outcomes of those interactions (Eggert et al., 2019).

In this paper, we elaborate on the concept of value creation in an ecosystemic setting by considering both dialogical and unidirectional interactions. This paper also proposes that the complexity involved in B2B value creation is not fully captured, when companies participating in $\mathrm{B} 2 \mathrm{~B}$ transactions are labelled conventionally as "buyers" and "sellers". This paper highlights the fact that B2B buyers and sellers are not individual actors. This topic is broadly acknowledged in the field of B2B sales, where multiple roles within buying organizations and their effect on organizational decision-making are widely discussed (Chandler and Johnston, 2012; Paesbrugghe et al., 2018; Paesbrugghe et al., 2017). Thus, it is beneficial to conceptualize the formation of agency within B2B value creation in more detail, as is the aim of this paper.

This conceptual paper aims to develop B2B sales and value creation theory. It, therefore, follows an envisioning approach that facilitates the discovery-phase of the discoveryjustification continuum (Yadav, 2010), which characterizes the development process of new knowledge (Hanson, 1958). Envisioning encompasses contributions that identify something new and extend our deep understanding of the phenomena under study (MacInnis, 2011). In this paper, we develop a theory by combining two theoretical streams - value creation and $\mathrm{B} 2 \mathrm{~B}$ sales - with anecdotal evidence from contemporary $\mathrm{B} 2 \mathrm{~B}$ sales settings. The paper aims to reveal unexplored areas in the field of value creation in B2B sales. By doing this the paper inspires empirical work to advance the knowledge development process to the phase of justification, thereby enabling further discovery (Yadav, 2010). To achieve this, this paper extends the literature on B2B sales (Grönroos and Voima, 2013; Haas et al., 2012; Hartmann et al., 2018), service-dominant logic (Vargo and Lusch, 2004, 2016) and the conceptualization of interactive value (co-)creation (Ramaswamy and Ozcan, 2018). The anecdotal evidence stemming from ethnographic follow-up in B2B sales within sales research projects is used to illustrate developed theoretical concepts.

The purpose of this paper is to conceptualize interactive value (co-)creation processes in an ecosystemic setting and to rethink the role of $\mathrm{B} 2 \mathrm{~B}$ sales through practical implications of our conceptualization. The paper contributes to the literature on $\mathrm{B} 2 \mathrm{~B}$ sales and value creation by introducing a conceptual model of interactive value (co-)creation in ecosystems, discussing the changing role of $\mathrm{B} 2 \mathrm{~B}$ sales and proposing an agenda for future research. In our conceptualization, the value in an ecosystemic environment is (co-)created when the processes of value proposition creation (VPC) - which includes all activities needed for a provider to bring a value proposition to a customer (Grönroos, 2011) - and the process of value idea emergence (VIE) - which involves the customer becoming aware of pursuable benefit - intertwine. Using this model, this paper broadens the discussion on $\mathrm{B} 2 \mathrm{~B}$ sales and value creation outside of the buyer-seller dyad where salespeople create value with customers, for example, as relationship builders (Weitz and Bradford, 1999), co-diagnosers (Aarikka-Stenroos and Jaakkola, 2012), change architects (Dixon and Tanner, 2012) and knowledge brokers (Verbeke et al., 2011). We propose that in an ecosystemic setting, the role of sales is to coordinate the intertwinement of VPC and VIE processes. With this paper, we hope to provoke further discussion by guiding both academic and managerial attention to interactions happening in the ecosystem outside of the buyer-seller dyad.

We begin by presenting the background on value creation in B2B sales. Next, we elaborate on key elements in our conceptualization, and then introduce the conceptual model of interactive value (co-)creation. We conclude by discussing how this novel approach to value (co-)creation is reflected in B2B sales, introducing practical implications of our conceptualization, presenting an agenda for future research and providing examples of possible research questions for future efforts.

\section{Value creation in business-to-business sales}

The role of B2B sales in creating and facilitating value has been widely acknowledged (Haas et al., 2012; Håkansson et al., 2009; Geiger et al., 2009). The important role of salespeople in value creation as relationship builders (Arli et al., 2018; Weitz and Bradford, 1999), co-diagnosers (Aarikka-Stenroos and Jaakkola, 2012), change architects (Dixon and Tanner, 2012) and knowledge brokers (Rapp et al., 2014; Verbeke et al., 2011) has been highlighted. Also, the strategic role of salespeople as a primary source of valuable customer insight, enabling the development of winning value propositions, has been acknowledged (Geiger et al., 2009). The topic of value creation has been mainly approached from the perspective of the dyadic relationship between customer and seller (for more discussion, see Grönroos and Voima, 2013; Homburg et al., 2009; Kowalkowski, 2011; Vargo and Lusch, 2008). However, besides dyadic approaches, more ecosystemic views of sales (Hartmann et al., 2018) and value creation (Vargo and Lusch, 2016) have started to emerge. 
An ecosystemic setting indicates that value creation and sales are the responsibility of all participants (Akaka and Vargo, 2014; Marcos Cuevas, 2018). Customers' complex needs introduce actors who may not have previously attended the traditional sales meetings (e.g. experts) in the B2B sales and value creation processes (Hartmann et al., 2018). To manage these more complex customer experiences, consisting of multiple interactions (Lemon and Verhoef, 2016), companies need to use all the internal (Hughes et al., 2012; Thaichon et al., 2018) and possibly external (Prahalad and Ramaswamy, 2004; Trainor, 2012) resources and capabilities they have access to. This places more emphasis on organizing not only the collaboration between sales and marketing (Malshe et al., 2017) but also within the organization as a whole, and between customers and other stakeholders (Arli et al., 2018; Marcos Cuevas, 2018; Paesbrugghe et al., 2017).

As the field of sales has become digitalized over the past decades (Singh et al., 2019), digital tools and new technologies have come to play a pivotal role in today's ecosystemic sales processes. Firstly, advanced technologies shape how B2B customers interact in the business environment in which buying and selling processes take place (Marcos Cuevas, 2018; Moncrief, 2017; Singh et al., 2019; Syam and Sharma, 2018.) Secondly, technologies, like social media (Agnihotri et al., 2016; Rodriguez et al., 2016) and artificial intelligence (Syam and Sharma, 2018), affect interactions within the sales process. This presents challenges to understanding value creation in $\mathrm{B} 2 \mathrm{~B}$ sales because buying processes are not limited to the dyadic relationship between buyer and seller but instead include different interactions with multiple entities (Lemon and Verhoef, 2016).

The following section elaborates on the topic of value creation in an ecosystemic environment by combining insights from the literature on value creation with illustrative examples from the field of $\mathrm{B} 2 \mathrm{~B}$ sales.

\section{Value (co-)creation in ecosystems - reflections from business-to-business sales}

As discussed above, several changes in the B2B landscape - such as digitalization, increased number of interaction touchpoints, changes in customer behaviour and global competition - have pushed B2B sales to an ecosystemic environment and transformed its role in value (co-)creation. Such an ecosystemic transition has also taken place in the wider spectrum of B2B sales and value creation (Aarikka-Stenroos and Ritala, 2017). Based on the literature on value creation and anecdotal evidence from practical B2B sales examples, this section develops a conceptual model of interactive value (co-)creation in ecosystems (Figure 1).

Our conceptualization constitutes four key concepts:

1 agencial assemblage, referring to actors in the $\mathrm{B} 2 \mathrm{~B}$ context;

2 interactive platforms, which describes elements that facilitate the interaction between agencial assemblages in the $\mathrm{B} 2 \mathrm{~B}$ environment;

3 VPC, which occurs through the interaction of agencial assemblages with interactive platforms and refers to all activities needed for a producer to bring a proposition to a customer; and

4 VIE, which refers to the process in which the agencial assemblage acknowledges and clarifies the pursuable benefit.

The following section starts by introducing each of these key concepts in more detail. Anecdotal evidence is used to illustrate each element. At the end of the section, the conceptual model of interactive value (co-)creation in ecosystems (Figure 1) is presented, bringing each of these elements together.

\subsection{Agencial assemblage}

The paper uses the concept of an agencial assemblage when discussing entities that take part in selling, buying and valuecreating actions. Organizational buyers are not individual actors. Different, possibly even conflicting roles within buying organizations and their effects on decision-making at the organizational level are widely discussed in the field of B2B sales (Chandler and Johnston, 2012; Paesbrugghe et al., 2018; Paesbrugghe et al., 2017). This complexity embedded within the interplay of agency and structure is relevant in B2B environments in general as multiple "agenting" entities are embedded in the wider organizational context in the form of individuals, teams and departments (March, 1988). To capture this complexity, this paper uses the concept of agencial assemblage, defined as:

Figure 1 Conceptual model of interactive value (co-)creation in an ecosystem

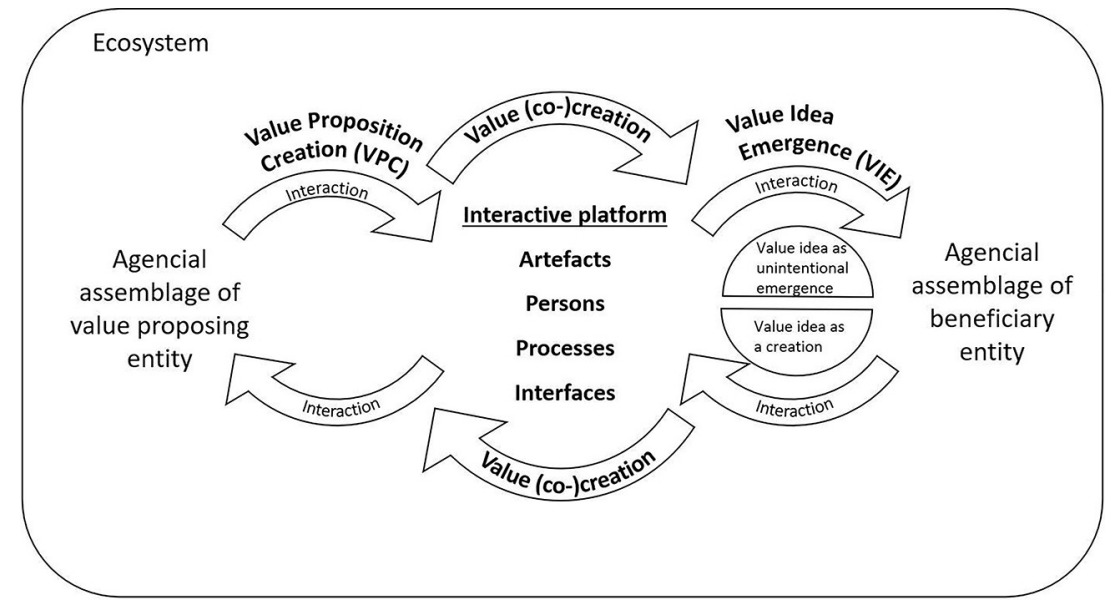


An arrangement endowed with the capacity of acting in different ways depending upon its combination of heterogeneous components [...] which are interrelated to one another in a way that brings about evolving patterns of actions [...] It is an "ensemble" as in terms of an arrangement of parts that work together for a certain time and a "process" as in terms of how those parts come together (Ramaswamy and Ozcan, 2018, p. 203).

The dualistic essence of the concept, which simultaneously describes an ensemble and a process, allows this paper to work with a more realistic conception of the B2B buyer and seller. Both are more precisely described as entities consisting of multiple parts and processes bringing those parts together, than merely as actors who buy or sell. Thus, we use this concept within our conceptualization of the role of B2B selling in value creation in ecosystems.

We draw a real-life example from a company in the field of business intelligence modelling in the construction industry that participated in our research project. The company provides a digital platform for a self-service ecosystem where the constructor and user of the facility, consultants and the owner can co-develop spaces. The use of this platform makes it part of the value creation between different actors. The platform also enables new processes for other parts of the organization to come together to co-develop the space. The digital platform is, thus, simultaneously a part of the organization and a part of the process bringing the organizational parts together.

\subsection{Interactive platforms}

Interactive platforms mediate all socio-material practices of interactions (Ramaswamy and Ozcan, 2018). The paper uses interactive platforms as a tool to understand value-creating interactions in ecosystems. Interactive platforms are also instantiations of agencial assemblages (Ramaswamy and Ozcan, 2018), and they form a second key element in our conceptualization.

Interactive platforms consist of APPI components, namely, artefacts, processes, people and interfaces. Artefacts include physical and digital things such as data in the form of numbers, text, audio, video or pictures. Processes consist of both the digitized and conventional business processes of interaction with another entity. People are individuals in the role of customers, employees or any other stakeholders. Interfaces include both physical and digitalized means by which an entity interacts with another entity (Ramaswamy and Ozcan, 2018).

Interactive platforms are not just intermediaries between different types of customers (Rochet and Tirole, 2006), nor are they modularizations of products (Gawer, 2014). Interactive platforms mediate all socio-material practices of interaction (Callon, 2016; Ramaswamy and Ozcan, 2018). It is also worth highlighting that the concept of the interactive platform should not be confused with conceptualizations of platforms as purely technological infrastructure. Different technological solutions may indeed be present within the different APPI components, but the concept is not defined by the involvement of technology.

APPI components define the ability of an entity to interact with other entities, thus forming both the "ensembles" in which different parts work together and the "processes" of different parts coming together. Each APPI component of the interactive platform can also comprise other APPI components. Ramaswamy and Ozcan (2018) use Facebook as an example and describe how digital artefacts, like newsfeeds and the "like button", form an entanglement of platform components together with the non-visible part data processes of the platform. The APPI components of interactive platforms are, thus, heterogeneous and can be part of multiple instantiations of agencial assemblages (Ramaswamy and Ozcan, 2018).

We further illustrate this concept by using an example from a company in the IT sector that helps companies find IT experts in their network to solve complex digital challenges in the B2B industry. This company used to recommend IT, experts, based on manual work between salespeople and buyers, relying on interactive platforms consisting mostly of people and company processes. The process of finding the right candidate was timeconsuming and demanded the identification of several suitable candidates for customer organizations' needs. The company understood that it needed to develop this process to make it more effective. It introduced digital interfaces for the use of its entire business network, including customers, employees, future employees, subcontractors and stakeholders.

Today, this process - which previously created value for salespeople and buyers mainly after the sale was made - is a valuable process for several different entities. For example, an IT expert is now able to share a video about himself, his work experience and his knowledge and can add information about his desired future working opportunities. The buying organizations and decision-makers are able to log into the ecosystem to find and select the right candidate with just one click. The future talents are able to market their knowledge and promote their skills to the more experienced teams. Based on all of the data, an IT company can, for example, forecast the future based on the movements of the actors in the ecosystem. This real-life business case example illustrates that different APPI components can enable value-creating interactions, even without the provider company's knowledge or formal activities.

\subsection{Value proposition creation}

This paper uses VPC to conceptualize the process of bringing value propositions to possible customers. This stems from service-dominant logic, whereby companies can merely propose a value to the market, which is then (co-)created by customers when they interact with the value propositions available to them (Kowalkowski, 2011; Vargo and Lusch, 2008). The process of proposing value or VPC, as labelled in this paper, includes all activities needed for a provider to bring a value proposition to a customer (e.g. design, development, manufacturing and delivery) (Grönroos, 2011). In this paper, we aim not to change this reasoning but to add that when following the logic of ecosystems, not just the actions of entity proposing value to potential customers should be considered. Thus, the statement is broadened to include the activities of all actors involved in creating value propositions or other ways of participating in value creation (Vargo and Lusch, 2011, 2016).

However, as previously stated, the term "actor" is too simplistic to describe the entities who buy and sell in a B2B environment accurately. Thus, we instead use the concept of "agencial assemblage" when describing the entity proposing value to potential customers. This paper proposes that VPC happens through the interaction of an agencial assemblage with interactive platforms, where the goal of the action guides interactions. To illustrate this concept, consider a copywriter engaged in the process of writing and publishing a text describing the features of a new product on the company's 
website. In this rather simple example of the process of communicating product information, the copywriter's interactions with his or her personal computer and its software artefacts form an agencial assemblage capable of writing and publishing a digital artefact (a product description) for potential customers to interact with. Naturally, the entire process of proposing value also consists of much more complex agencial assemblages and interactions than the one described above. However, the logic of agencial assemblages formed through the intended aim (in the above example, the need to fulfil a given task to publish a text) and interactions with APPI components remain similar.

Another example is a B2B medical technology company that operates globally. The company offers technology-based medical solutions to improve the quality of human life. Its product, a medical device that models brains, supports healthcare professionals in their work with the help of technology that operates based on algorithms and mathematics. It has already been successful in its business, and the best surgeons want to share their insights about this medical device and how they have used advanced technology to be more successful in their own work as surgeons. This medical technology company uses its customers' knowledge as part of its customer-centric operations. For example, it organizes events where many of the most respected surgeons in the world are invited to share their knowledge. Recently, it has started to share short videos on social media platforms (e.g. LinkedIn) in which health-care experts search for new information and best practices for their works. This anecdotal example illustrates shared VPC through interaction with APPI components. In this example, VPC occurs through interaction with customers as the company is able to improve value propositions based on feedback gathered from events and discussions on social media platforms.

\subsection{Value idea emergence}

In this section, we propose the concept of VIE: the process in which a B2B customer becomes aware of a benefit worth pursuing (i.e. the emergence of an idea of value) and sharpens his or her expectations towards this benefit. By introducing this concept, we are then able to conceptualize value (co-)creation in ecosystems in a way that accounts for interactions preceding the ones involved in value propositions. Through the concept of VIE, it is possible to understand B2B sales in ecosystems through the lens of value creation.

The concept of VIE includes a heterogeneous set of interactions with different actors playing different roles in the emergence and sharpening of an idea of a pursued value. We emphasize that VIE is a process that not only takes place before but also during, interactions with the value proposition. We suggest that the valuable experience of the customer is better described as a process consisting of multiple interactions, given that:

- the relational context of interactions is shaped by the interaction between actors, rather than given (Snehota, 2004); and

- the interpretation of an actor determines both the amount of value created through interactions (Vargo and Lusch, 2004) and the expectations of the value created through consecutive interactions (Eggert et al., 2019).
We propose that in an ecosystemic setting, it is trivial whether the interaction through which these expectations are formed occurs between value proposers or any other actor (e.g. media, blog post, conference presentation, personal social network).

Hartmann et al. (2018) describe similar observations using the example of cloud services. The probability of a customer buying a particular cloud service partly depends on the customer's perception of cloud services in general (Hartmann et al., 2018). In other words, customers might have formed expectations of the value of a particular cloud service before even acknowledging the existence of this specific service.

We propose that, like VPC, the process of VIE happens through interactions with APPI components of the interactive platform. As an illustration, we use an anecdotal example that emerged during an interview with a customer segment manager of a company that provides certification services. The company operates in multiple countries and industries, so its purchase needs are, in most cases, related to expertise in specific industries or the legislation of a specific country. A customer segment manager at the company described how their buying process usually starts with the needs of their own customers. Consultants working on customers' projects inform the company of any possible buying needs, which then are advanced in a more formal buying process led by specific managers. In the case of this company, value ideas emerge through the interaction between customers and consultants and are further sharpened in a more formal process of deciding what will be bought and how. Like all socio-material interactions, these interactions are mediated by interactive platforms.

It is important to highlight the mechanisms between interactions and the process within an agencial assemblage. In the above example, consultants who first developed a value idea pursued it further by informing the organization about the possible purchases needed to complete the project. In other words, the value idea led consultants to interact with the managers responsible for the later parts of the purchase process. This interaction describes how parts of an organizational entity can be brought together, forming an ensemble capable of advancing the purchase process. Considering both the mechanism for emergence and sharpening of the value idea, as well as the mechanisms for the process within agencial assemblage, the paper defines VIE as follows:

Value idea emergence is a process entailing the value idea as an emerging outcome without the embodied experience of engagement and creation embedding the intention, guiding the agential assemblage of the beneficiary entity in service exchange.

Value ideas can emerge through interaction unintentionally and without engaging with them, but they can also be intentionally created and sharpened. In the above example, consultants' interactions with the customer were not motivated by the desire to find a need for purchase. Rather, the value idea emerged through interactions that occurred while working on the customer's problem. After it emerged, the sharpening of value idea became a more intended process, focussed on forming more precise expectations towards the concrete ways of satisfying the need identified by the consultant. Value ideas also guide the agencial assemblage. In the example, consultants alone were not able to finish the purchase process by themselves. However, the value idea drove them to interact with the managers responsible for purchases (i.e. it guided the agencial assemblage) and share their idea, allowing it to be pursued further. 


\subsection{Conceptual model of interactive value (co-)creation in ecosystems}

Finally, we conclude this section by proposing a conceptual model of interactive value (co-)creation. This model synthesizes four previously described key elements to explain how to value ideas emerge and co-create value in ecosystemic settings. The VPC and VIE processes are motivated by Hartmann et al. (2018) and Ramaswamy and Ozcan's (2018) theories and are furthermore fuelled by anecdotal evidence from B2B sales. In Figure 1, the individual processes of VPC and VIE are modelled with arrows demonstrating interactions between the APPI components of an interactive platform. Value (co-)creation is thought to happen when the processes of VIE and VPC occur in a shared APPI component of an interactive platform, allowing two processes to intertwine.

In Figure 1, the arrows between VPC and VIE illustrate value (co-)creation through the intertwinement of the two processes. In this intertwinement, the agencial assemblages of the value proposer and beneficiary entity interact through the shared APPI components of the interactive platform - such as a salesperson (people), company website (artefacts and possible interface) or social media platform (interface). Value is simultaneously evaluated with regard to expectations (Kim and Stoel, 2005), and the idea of future value is further elaborated on the basis of experienced value in interactions (Eggert et al., 2019). The process within the agencial assemblage also continues to happen through value (co-)creation. New actors can still be introduced to both processes regardless of their intertwinement.

In the next section, contributions of the model, implications of the model for $\mathrm{B} 2 \mathrm{~B}$ sales and practical implications are discussed. An agenda for future research intended to prompt further discussion is presented.

\section{Conclusions, practical implications and future research agenda}

This paper contributes to the literature on value creation (Grönroos and Voima, 2013; Haas et al., 2012; Prahalad and Ramaswamy, 2004; Ramaswamy and Ozcan, 2018; Vargo and Lusch, 2008, 2011) by conceptualizing VPC and VIE. Additionally, this paper contributes to the discussion by broadening the role of $\mathrm{B} 2 \mathrm{~B}$ sales to include not only interactions that salespeople participate in but also those they do not participate in. In this way, it highlights interactions not shared by value-proposing and beneficiary entities, but that takes place in a larger ecosystem. The literature has mainly focussed on the perspective of the dyadic B2B buyer-seller relationship, where salespeople create value with customers as relationship builders, co-diagnosers of value and change architects (Aarikka-Stenroos and Jaakkola, 2012; Grönroos and Voima, 2013; Dixon and Tanner, 2012; Weitz and Bradford, 1999). Next, we elaborate on this approach to the relationship between $\mathrm{B} 2 \mathrm{~B}$ sales and value creation.

\subsection{Business-to-business sales coordinating the intertwinement of value proposition creation and value idea emergence}

The model presented in Figure 1 builds on the ecosystemic understanding of value creation by conceptualizing the set of heterogeneous interactions that take place in VPC and VIE before the two processes are intertwined. These interactions are as crucial as those that happen during (co-)creation as they set expectations and the starting point for (co-)creation. We consider this addition relevant, as technological advancements have already brought some of these interactions within reach of sales and marketing professionals. For example, marketing automation software and advanced customer resource management system (e.g. HubSpot, Salesforce, Marketo, Pipedrive) can, to some extent, track interactions that a beneficiary entity has participated in within an online environment, both before and after interacting with the landing page of the value-proposing entity.

In addition to constantly developing sales tools, Internet of Things solutions and smart devices have opened different ways for value-proposing entities to access the VIE processes of beneficiary entities. Consider, for example, sophisticated elevators or cranes, which are constantly transmitting data regarding their operation and thereby enabling the response to service needs before the current customers of the company become aware of such needs. Technological advancements have also enabled sales and marketing professionals better tools to track VPC processes. Managers in IT consulting companies who participate in sales research projects have described how their enterprise resource planning systems offer salespeople tools to view which experts are available for customer projects, and thus better plan what solutions can be offered to a customer at any given time.

We propose that the role of $\mathrm{B} 2 \mathrm{~B}$ sales in an ecosystemic setting is to coordinate the intertwinement of the VPC and VIE processes. In an ecosystemic setting, this coordination requires organizations to have not only advanced tools but also the mindset to see VIE and VPC as something happening outside of an organization. On a practical level, this constitutes two questions:

Q1. How well does our organization understand VIE and VPC interactions in which we are not involved?

Q2. When (or if) our organization participates in VPC and VIE interactions, how well do the actions of our organization align with previous interactions that our organization did not participate in?

In the next section, we discuss the practical implications of our approach in more detail.

\subsection{Practical implications}

Our conceptual model of interactive value (co-)creation in ecosystems (Figure 1) proposes that VIE and VPC processes may emerge in different kinds of interactions between several actors in an ecosystem. To coordinate the intertwinement of these two processes, the interactions within these processes should be known to the greatest extent possible, regardless of whether or not the organization has participated in them. In the process of VPC, information on interactions cuts across all parts of the organization. For sales organizations to understand the full potential of a value proposition, it must have access to information on the interactions that constitute the VPC. This requires the commitment of the whole organization to ensuring knowledge flows between entities participating in VPC to the greatest extent possible. This is also crucial for using valuable 
customer knowledge carried by sales and marketing in other parts of the VPC process.

Formulating and communicating a value proposition so that it aligns with the ongoing process of VIE requires information on interactions that have taken place in VIE before the interactions with salespeople. In most cases, following the actions of prospects in an online environment is the responsibility of the marketing department. To ensure that this valuable information does not get lost, the collaboration between sales and marketing person needs to be improved and the organizational silos need to be collapsed for customercentric operations. In the worst cases, disconnects between sales and marketing may be experienced from the customers' side, ending what began as a promising buying path. Sales organizations need to understand both online and offline interactions as a part of a singular process of VIE, not as two separate entities. These changes in collaboration and organization structures require managerial activities. It is also beneficial to be aware that many VIE interactions are totally out of reach for both sales and marketing. These may include interactions between different employees of the B2B buyer and their private interactions outside of work.

Understanding the interactions happening in both VPC and VIE requires digitized customer-centric activities. This involves enhancing advanced digital tools, social media, marketing and sales automation for the entire customer journey. As a practical implication, it is crucial that salespeople become familiar with the sales technologies and start to use them (in the best cases, eventually feeling unable to work without them) (Singh et al., 2019). Moreover, investments into new sales technologies, like sales automation and customer resource management systems are the cornerstones for developing VPC and VIE processes.

In addition to technological investments, this change needs strong leadership to activate the whole organization and management to change structures to better fit the needs of today's ecosystemic business environments (Marcos Cuevas, 2018; Corsaro, 2019; Hartmann et al., 2018). For both the managerial and salespeople level, development programmes are essential parts of this digital transformation and widespread collaboration with companies. Without collaboration and a common understanding of the customer journey, the utilization of technological tools may be useless. Moreover, the digitalization and opportunities to create value on different social media platforms call for utilization in companies (Ammirato et al., 2019.) This indicates that there may still be several challenges to building value propositions and co-creating value with customers, not only in customer-centric functions but also with value-creating entities.

\subsection{Future research agenda}

To manage and coordinate the intertwinement of VPC and VIE in sales ecosystems and to study the identified research topics more extensively, we suggest that the topics mentioned in Table 1 be elaborated on. The research agenda presented in Table 1 is motivated by the conceptual model of interactive value (co-)creation in ecosystems and considers five major research areas to improve our understanding of the intertwinement of VPC and VIE:

1 agencial assemblage of the value-proposing entity;

2 VPC;

3 agencial assemblage of the beneficiary entity;

4 VIE; and

5 value (co-)creation process intertwinement.

To advance this work, the next step in future research would be to study the suggested conceptual framework in different realworld settings. This would also include empirical research on

Table 1 Research agenda for value creation and B2B sales in an ecosystemic setting

\begin{tabular}{|c|c|}
\hline Research theme & Research questions/topic \\
\hline Agencial assemblage of the value-proposing entity & $\begin{array}{l}\text { - How can companies identify and create the most valuable parts and processes } \\
\text { within agencial assemblages? } \\
\text { - How can these most valuable parts and processes be used in companies? }\end{array}$ \\
\hline Value proposition creation & $\begin{array}{l}\text { - How can the different phases in *VPC be conceptualized? } \\
\text { - What kind of interactions can be included in the VPC processes? } \\
\text { - To what extent are organizations able to manage VPC processes consisting } \\
\text { of multiple actors? To what extent is managing beneficial for organizations? }\end{array}$ \\
\hline Agencial assemblage of the beneficiary entity & $\begin{array}{l}\text { - How can we conceptualize the beneficiary entities in sales ecosystems? } \\
\text { - What kind of processes support beneficiary entities' value creation? }\end{array}$ \\
\hline Value idea emergence & $\begin{array}{l}\text { - How can the APPI components of an interactive platform support } \\
\text { information flow and data gathering? } \\
\text { - What technologies could be harnessed for data gathering in each } \\
\text { component of the interactive platform to gain access to **VIE? } \\
\text { - What kind of actions are needed to coordinate the VIE processes? } \\
\text {-What is the exact role of sales in VIE? How can VIE be facilitated? }\end{array}$ \\
\hline Value (co-)creation process intertwinement & $\begin{array}{l}\text { - How can organizations gain access to their prospective customers' VIE } \\
\text { processes? } \\
\text { - How can intertwinement needs to be managed in sales organizations? }\end{array}$ \\
\hline
\end{tabular}

Notes: *Value proposition creation - the process, which includes all activities needed for bringing value proposition to a customer. ${ }^{* *}$ Value idea emergence - the process through which B2B entities become aware of a pursuable benefit 
how actors such as sales-centric people in supplier organizations, coordinate the intertwinement of VPC and VIE to (co-)create value. Further research is also needed to explore the development of VIE and the VPC model in service ecosystem settings.

\section{References}

Aarikka-Stenroos, L. and Jaakkola, E. (2012), "Value cocreation in knowledge intensive business services: a dyadic perspective on the joint problem solving process", Industrial Marketing Management, Vol. 41 No. 1, pp. 15-26.

Aarikka-Stenroos, L. and Ritala, P. (2017), "Network management in the era of ecosystems: systematic review and management framework", Industrial Marketing Management, Vol. 67, pp. 23-36.

Agnihotri, R., Dingus, R., Hu, M.Y. and Krush, M.T. (2016), "Social media: influencing customer satisfaction in B2B sales", Industrial Marketing Management, Vol. 53, pp. 172-180.

Akaka, M.A. and Vargo, S.L. (2014), "Technology as an operant resource in service (eco)systems", Information Systems and e-Business Management, Vol. 12 No. 3, pp. 367-384, doi: 10.1007/s10257-013-0220-5.

Ammirato, S., Felicetti, A.M., Della Gala, M., AramoImmonen, H., Jussila, J.J. and Kärkkäinen, H. (2019), “The use of social media for knowledge acquisition and dissemination in B2B companies: an empirical study of finnish technology industries", Knowledge Management Research \& Practice, Vol. 17 No. 1, pp. 52-69.

Arli, D., Bauer, C. and Palmatier, R.W. (2018), "Relational selling: past, present and future", Industrial Marketing Management, Vol. 69, pp. 169-184.

Baldwin, C.Y. (2008), "Where do transactions come from? Modularity, transactions, and the boundaries of firms", Industrial and Corporate Change, Vol. 17 No. 1, pp. 155-195.

Ballantyne, D. and Varey, R.J. (2006), "Creating value-in-use through marketing interaction: the exchange logic of relating, communicating and knowing", Marketing Theory, Vol. 6 No. 3, pp. 335-348, doi: 10.1177/1470593106066795.

Callon, M. (2016), "Revisiting marketization: from interfacemarkets to market-agencements", Consumption Markets $\mathcal{E}$ Culture, Vol. 19 No. 1, pp. 17-37.

Chandler, J. and Johnston, W. (2012), "The organizational buying center as a framework for emergent topics in business-to-business marketing", Advances in Business Marketing and Purchasing, Vol. 18, pp. 41-87.

Corsaro, D. (2019), "Capturing the broader picture of value co-creation management", European Management fournal, Vol. 37 No. 1, pp. 99-116, doi: 10.1016/j.emj.2018.07.007.

D'Haen, J., Van Den Poel, D., Thorleuchter, D. and Benoit, D.F. (2016), "Integrating expert knowledge and multilingual web crawling data in a lead qualification system”, Decision Support Systems, Vol. 82 No. 2, pp. 69-78.

Dixon, A.L. and Tanner, J.F. (2012), "Transforming selling: why it is time to think differently about sales research", Fournal of Personal Selling \& Sales Management, Vol. 32 No. 1, pp. 9-14.

Eggert, A., Kleinaltenkamp, M. and Kashyap, V. (2019), "Mapping value in business markets: an integrative framework", Industrial Marketing Management, Vol. 79, pp. 13-20, doi: 10.1016/j.indmarman.2019.03.004.
Gawer, A. (2014), "Bridging differing perspectives on technological platforms: toward an integrative framework", Research Policy, Vol. 43 No. 7, pp. 1239-1249, doi: 10.1016/ j.respol.2014.03.006.

Geiger, S., Guenzi, P., Storbacka, K., Ryals, L., Davies, I.A. and Nenonen, S. (2009), "The changing role of sales: viewing sales as a strategic, cross-functional process", European Fournal of Marketing, Vol. 43 No. 7, pp. 890-906.

Grönroos, C. (2011), "Value co-creation in service logic: a critical analysis", Marketing Theory, Vol. 11 No. 3, pp. 279-301, doi: 10.1177/1470593111408177.

Grönroos, C. and Voima, P. (2013), "Critical service logic: making sense of value creation and co-creation", fournal of the Academy of Marketing Science, Vol. 41 No. 2, pp. 133-150, doi: 10.1007/s11747-012-0308-3.

Haas, A., Snehota, I. and Corsaro, D. (2012), "Creating value in business relationships: the role of sales", Industrial Marketing Management, Vol. 41 No. 1, pp. 94-105, doi: 10.1016/j. indmarman.2011.11.004.

Håkansson, H., Ford, D., Gadde, L.E., Snehota, I. and Waluszewski, A. (2009), Business in Networks, John Wiley \& Sons, Chichester.

Hanson, N.R. (1958), Patterns of Discovery, University Press, Cambridge, UK.

Hartmann, N.N., Wieland, H. and Vargo, S.L. (2018), "Converging on a new theoretical foundation for selling", fournal of Marketing, Vol. 82 No. 2, pp. 1-18, doi: 10.1509/ jm.16.0268.

Hohenschwert, L. and Geiger, S. (2015), "Interpersonal influence strategies in complex B2B sales and the sociocognitive construction of relationship value", Industrial Marketing Management, Vol. 49, pp. 139-150.

Homburg, C., Wieseke, J. and Bornemann, T. (2009), "Implementing the marketing concept at the employeecustomer interface: the role of customer need knowledge", Fournal of Marketing, Vol. 73 No. 4, pp. 64-81.

Hughes, D.E., Le Bon, J. and Malshe, A. (2012), "The marketing-sales interface at the interface: creating market-based capabilities through organizational synergy", fournal of Personal Selling \& Sales Management, Vol. 32 No. 1, pp. 57-72.

Kim, M. and Stoel, L. (2005), "Salesperson roles: are online retailers meeting customer expectations?", International foumal of Retail E Distribution Management, Vol. 33 No. 4, pp. 284-297.

Kowalkowski, C. (2011), "Dynamics of value propositions: insights from service-dominant logic", European fournal of Marketing, Vol. 45 Nos 1/2, pp. 277-294.

Lemon, K.N. and Verhoef, P.C. (2016), "Understanding customer experience throughout the customer journey", Fournal of Marketing, Vol. 80 No. 6, pp. 69-96.

MacInnis, D.J. (2011), "A framework for conceptual contributions in marketing", fournal of Marketing, Vol. 75 No. 4, pp. 136-154.

Malshe, A., Johnson, J.S. and Viio, P. (2017), "Understanding the sales-marketing interface dysfunction experience in business-to-business firms: a matter of perspective", Industrial Marketing Management, Vol. 63, pp. 145-157.

March, J.G. (1988), Decisions and Organizations, WileyBlackwell, Oxford.

Marcos Cuevas, J. (2018), "The transformation of professional selling: implications for leading the modern sales organization", 
Industrial Marketing Management, Vol. 69, pp. 198-208, doi: 10.1016/j.indmarman.2017.12.017.

Moncrief, W.C. (2017), "Are sales as we know it dying ... or merely transforming?”, Fournal of Personal Selling \& Sales Management, Vol. 37 No. 4, pp. 271-279, doi: 10.1080/ 08853134.2017.1386110.

Paesbrugghe, B., Sharma, A., Rangarajan, D. and Syam, N. (2018), "Personal selling and the purchasing function: where do we go from here?", fournal of Personal Selling \& Sales Management, Vol. 38 No. 1, pp. 123-143.

Paesbrugghe, B., Rangarajan, D., Sharma, A., Syam, N. and Jha, S. (2017), "Purchasing-driven sales: matching sales strategies to the evolution of the purchasing function", Industrial Marketing Management, Vol. 62, pp. 171-184.

Prahalad, C.K. and Ramaswamy, V. (2004), "Co-creation experiences: the next practice in value creation", fournal of Interactive Marketing, Vol. 18 No. 3, pp. 5-14.

Ramaswamy, V. and Ozcan, K. (2018), "What is co-creation? An interactional creation framework and its implications for value creation", Fournal of Business Research, Vol. 84, pp. 196-205, doi: 10.1016/j.jbusres.2017.11.027.

Rapp, A., Bachrach, D.G., Panagopoulos, N. and Ogilvie, J. (2014), "Salespeople as knowledge brokers: a review and critique of the challenger sales model", Fournal of Personal Selling E Sales Management, Vol. 34 No. 4, pp. 245-259, doi: 10.1080/08853134.2014.908126.

Rochet, J.C. and Tirole, J. (2006), "Two-sided markets: a progress report", The Rand fournal of Economics, Vol. 37 No. 3, pp. 645-667.

Rodriguez, M., Ajjan, H. and Peterson, R.M. (2016), "Social media in large sales forces: an empirical study of the impact of sales process capability and relationship performance", fournal of Marketing Theory and Practice, Vol. 24 No. 3, pp. 365-379.

Singh, J., Flaherty, K., Sohi, R.S., Deeter-Schmelz, D., Habel, J., Le Meunier-FitzHugh, K., Malshe, A., Mullins, R. and Onyemah, V. (2019), "Sales profession and professionals in the age of digitization and artificial intelligence technologies: concepts, priorities, and questions", Fournal of Personal Selling Eऽ Sales Management, Vol. 39 No. 1, pp. 2-22.

Snehota, I. (2004), "Perspectives and theories of market", in Håkansson, H., Harrison, D. and Waluszewski, A. (Eds), Rethinking Marketing: developing a New Understanding of Markets, John Wiley and Sons, Chichester.

Steward, M., Narus, J., Roehm, M. and Ritz, W. (2019), "From transactions to journeys and beyond: the evolution of B2B buying process modeling”, Industrial Marketing Management, Vol. 83 No. 11, pp. 288-300.

Syam, N. and Sharma, A. (2018), "Waiting for a sales renaissance in the fourth industrial revolution: machine learning and artificial intelligence in sales research and practice", Industrial Marketing Management, Vol. 69, pp. 135-146, doi: 10.1016/j. indmarman.2017.12.019.

Thaichon, P., Surachartkumtonkun, J., Quach, S., Weaven, S. and Palmatier, R.W. (2018), "Hybrid sales structures in the age of e-commerce", Fournal of Personal Selling \& Sales Management, Vol. 38 No. 3, pp. 277-302.
Trainor, K.J. (2012), "Relating social media technologies to performance: a capabilities-based perspective", fournal of Personal Selling \& Sales Management, Vol. 32 No. 3, pp. 317-331.

Vargo, S.L. and Lusch, R.F. (2004), "Evolving to a new dominant logic for marketing", fournal of Marketing, Vol. 68 No. 1, pp. 1-17, doi: 10.1509/jmkg.68.1.1.24036.

Vargo, S.L. and Lusch, R.F. (2008), "Service-dominant logic: continuing the evolution", fournalof the Academy of Marketing Science, Vol. 36 No. 1, pp. 1-10.

Vargo, S.L., Lusch, R.F. (2011), "It's all B2B. . and beyond: toward a systems perspective of the market", Industrial Marketing Management, Vol. 40 No. 2, pp. 181-187, doi: 10.1016/j.indmarman.2010.06.026.

Vargo, S.L. and Lusch, R.F. (2016), "Institutions and axioms: an extension and update of service-dominant logic", fournal of the Academy of Marketing Science, Vol. 44 No. 1, pp. 5-23, doi: 10.1007/s1 1747-015-0456-3.

Verbeke, W., Dietz, B. and Verwaal, E. (2011), "Drivers of sales performance: a contemporary meta-analysis. Have salespeople become knowledge brokers?", fournal of the Academy of Marketing Science, Vol. 39 No. 3, pp. 407-428, doi: 10.1007/s11747-010-0211-8.

Weitz, B.A. and Bradford, K.D. (1999), "Personal selling and sales management: a relationship marketing perspective", Fournal of the Academy of Marketing Science, Vol. 27 No. 2, pp. 241.

Yadav, M.S. (2010), "The decline of conceptual articles and implications for knowledge development", fournal of Marketing, Vol. 74 No. 1, pp. 1-19.

Zanette, M.C., Brito, E.P.Z. and Coutinho, M. (2013), "New influentials: an exploratory study on blogs", Fournal of Direct, Data and Digital Marketing Practice, Vol. 15 No. 1, pp. 36-46, doi: 10.1057/dddmp.2013.45.

\section{Further reading}

Liu, A.H. and Leach, M.P. (2001), "Developing loyal customers with a value-adding sales force: examining customer satisfaction and the perceived credibility of consultative salespeople", fournal of Personal Selling E Sales Management, Vol. 21 No. 2, pp. 147-156.

Marshall, G.W., Moncrief, W.C., Lassk, F.G. and Shepherd, D. (2012), "Linking performance outcomes to salesperson organizational citizenship behavior in an industrial sales setting”, Fournal of Personal Selling \& Sales Management, Vol. 32 No. 4, pp. 491-501.

Panagopoulos, N.G., Rapp, A.A. and Ogilvie, J.L. (2017), "Salesperson solution involvement and sales performance: the contingent role of supplier firm and customer-supplier relationship characteristics", fournal of Marketing, Vol. 81 No. 4, pp. 144-164.

\section{Corresponding author}

Sami Rusthollkarhu can be contacted at: sami.rusthollkarhu@ tuni.fi

For instructions on how to order reprints of this article, please visit our website:

www.emeraldgrouppublishing.com/licensing/reprints.htm

Or contact us for further details: permissions@emeraldinsight.com 